\title{
The Politics Of Muslim Identity And The Personal Laws: Safeguarding The Rights Of The Internal Minorities
}

\author{
Vikram Gautam \\ Research Scholar, Department of Political Science, University of Delhi, Delhi
}

\begin{abstract}
Any discourse regarding the advancement of minority community could not be carried out successfully in the absence of taking up concerns of its own internal challenges and issues of intra-group equality. Muslim Personal Law is one such important challenge that continuously reframes the discourse of politics of Muslim identity. It is obvious that almost all personal laws relegate position of women and are discriminatory in nature, even though over the time, a lot of reforms have been done in personal laws of the Hindu, Christian as well as in Parsi communities. Although these reforms in personal laws are not entirely gender sensitive, but somehow they have progressed and transformed considerably towards an effective course of action. On the contrary, the same developments are still remaining to happen in case of the Muslim Personal Laws. On account of this, dominant groups of the society insist on corresponding reformative measures to remove such anomaly and demand homogenous and uniform personal laws in India. The Muslim women, focus of our study, face the similar situation at the hands of their own community by imposing various gender-biased personal laws. These personal laws violate the basic individual rights of women in the name of community values. Therefore, a comprehensive assessment of these personal laws needs to be done. This article analyse the challenges of the internal minorities within minority groups and corresponding measures to ensure them just and equable rights. It will further explore the conflict that occurs between internal minority and her cultural group and demonstrates the perils of multicultural accommodation in a liberal democratic society.
\end{abstract}

Key words: Muslim Minority, Personal Laws, Women Rights, Uniform Civil Code, Intra-group Equality

\section{INTRODUCTION}

All cultural communities desire to preserve and uphold their cultural attributes for future generations. For this purpose, they wanted specific recognition and wide acceptance in the public sphere to keep them attractive for its constituent members. Predominantly, all cultural communities are internally differentiated as well as structurally heterogeneous with internal hierarchies present within the group. As a result, the dominant members of the group suppress and deny equal rights to their own internal minority. Addressing the issue of internal minorities, Leslie Green said, " minority groups are rarely homogeneous, they often contain other minorities some of the ways in which we try to ensure that minorities rights not oppressed by majorities make it more likely that those minorities are able to oppress its own internal minorities" [1]. The multicultural framework which promotes inter-group equality, by and large, remains insensitive towards intra-group equalities. There is a need to accept these internal differentiation and hierarchies present within a cultural group. It is of much significance that how these minority groups identify and express themselves and more specifically extend equal treatment to its own constituent members. To put it simply, cultural groups should not oppress their own internal minorities like women and provide them equal and gender-just rights. Leslie Green further elaborates "When minorities are thus organised and disciplined they are given a clear voice and become stronger, but they often silence and disempowered internal minorities in doing so... The issue of protecting autonomy and equality of their internal minorities is as important as the protection of minority groups from dominant or majority group. By providing special cultural rights to minority group; community can empower them to become oppressive and persecute their internal heterogeneous voices. These issues are sometime not well attended by the community leadership" [2]. Therefore, it becomes imperative to ensure proper protection to these internal minorities and devises powerful and effective measures for their equal participation and representation.

The politics of diversity emphasises protection of personal laws and religious values and restricts them within the private sphere of the community. This conception of private sphere further nurtures the subordination of female members of the minority group. Besides, the non-interventionist approach of the state in the private sphere of cultural groups impedes the process of internal democratisation and progress of reformative measures. The policy of non-interference in private affairs of a religious community viz. the Muslim community has proved detrimental for the struggle of gender equality. It reinforces the role of conservative leadership and paternalistic power structures, present within the community and institutionalised the subjection and suppression 
of women and confines them to their stereotypical roles. The Muslim women, focus of our study, face the similar situation at the hands of their own community by imposing various gender-biased personal laws. These personal laws violate the basic individual rights of women in the name of community values. Therefore, a comprehensive assessment of these personal laws needs to be done.

\section{SUBJECTION OF MUSLIM WOMEN THROUGH PERSONAL LAWS}

Muslim women in India come across a lot of concerns as a member of the Muslim community. Their deplorable socio-economic position echoes their vulnerable status in the society. Zoya Hasan rightly describes, "Muslim women are triply disadvantaged - as members of a minority, as women, and most of all as poor women"[3]. Even if, this is not specific to Muslim women but their problems are much more critical than their counterparts of other communities. As highlighted by Sachar Committee Report, Muslim women as a whole suffer discrimination in every aspect of public domain like education, job opportunities and benefits of welfare initiatives. They are the obvious victims of the unjust traditional practices and leg behind in almost all developmental indexes. AyeletShachar specifies, "minority group members such as women who are subject to strict intra-group controls and sanctioned maltreatment are precisely those members who commonly lack the economic stability, cultural 'knowhow', language skills, connections, and self-confidence'[4]. Both Muslim women and the Muslim community altogether tend to be identified through inviolable and immutable 'Islamic' traditional values, resultantly Muslim women's social status is defined by these inherent perpetual norms of the community. Religious, ideological and moral values determined the woman's position and virtues in the society. Women are regarded as the sole bearer of religious identity and traditional values. Virtually all the initiatives for attaining gender justice, therefore, rest on the desirability of the community to reform their personal law on their own way. Sometimes the situation is exaggerated by the majority-minority politics and demands of a uniform civil code are raised which would be applicable to all citizens irrespective of their religion. Thus, the core issue of gender equality and socio-economic vulnerability of women more or less remains unattended.

The endeavour of reforms in Muslim Personal Law is considerably complicated by the overall marginalisation and vulnerable position of the Muslim minority. Sachar Committee Report illustrated this fact as Muslims are markedly impoverished, under-represented and marginalised in public employment, education, and development. Muslims have been constitutionally provided cultural and religious rights in addition to the unique personal laws in matter of marriage, inheritance, adoption, and succession etc. Accordingly for Muslim women, their interest and articulations continue to be firmly regulated and expressed through the notions of minority identity discourse. The conservative and orthodox members of the Muslim society dominated the discourse of reforms in the Muslim Personal Law. These patriarchal oriented dominant groups of the community stifle and curtail women's freedom and equality in guise of religious traditions and values.

On the other hand, those who always insist that reforming in Muslim personal law is the only available solution of gender justice and eventually will improve their condition substantially, overlook the fact that it will essentialize and freeze women's identity within a cultural framework. It ignores the fact of the multiple and diversified identity of Muslim women that depends on various factors like language, caste together with regional attributes. This frame of mind, generally, based on the premise of homogeneous structure of Muslim community and did not acknowledge the different hierarchies present within the community. This reinforces dominant conservative and gender-biased structures within the minority group and further complicates the issue of reforms in Muslim Personal Law. The issue of personal law is linked with religious identity of the Muslim minority community and, therefore, the whole community resists the change as their religious leaders claim immutability of these codes. It becomes a matter of significance for all Muslims because it frames and reframes their religious identity. Moreover, there are anxieties within Muslims that any change in their personal laws will provide an impetus for imposing majoritarian norms on the community. Thus Muslim women by and large become trapped in contestation between majority and minority groups.

Undoubtedly, the arrangement of specific personal laws of each community has caused social and legal challenges before the state and society. It intensifies the debate further that whether personal laws to be permitted or not in a democratic society. Would just by replacing the personal law with uniform civil code address the issue of women subordination and provide them equal rights?

\section{CONSTITUTIONAL PROTECTIONS FOR THE PERSONAL LAWS}

There were tremendous challenges at the time of independence for making a liberal, democratic and integrated nation especially following the tragic incident of partition on religious basis. These challenges were aggravated by the enormous linguistic, cultural, religious, racial, and ethnic multiplicity existed in the country. The framers of the Indian Constitution adopted a pluralistic and multicultural approach to accommodate such a colossal diversity along with reconciling the demands of national unity and inter-group contestations. The Indian Constitution provided equal fundamental rights to all its citizens irrespective of their caste, creed and religion. In addition to these rights, safeguards were provided to cultural and religious minorities by granting them rights to 
preserve their specific cultural and religious practices. As described by Granville Austin, "India was a land of communities, of minorities, racial, religious, linguistic social and caste...Indians believed that in their 'federation of minorities' a declaration of rights was as necessary as it had been for the Americans" [5].

The Indian Constitution acknowledged the importance of community rights and allowed different religious communities to keep their separate personal laws governing the matters of marriage, inheritance, succession etc. However, several members of the Constituent Assembly, especially the women representatives, strongly opposed these personal laws as they nurtured patriarchal dominance and undermined women's fundamental right of equality. Despite such a considerable opposition, the Constituent Assembly allowed freedom of religious practices to all communities. Personal laws of different religious communities were left for them to decide. The provision for the uniform civil code was incorporated as an article 44 in non-enforceable Directive Principles of State Policy as 'the State shall endeavour to secure for the citizens a uniform civil code throughout the territory of India'. B.R. Ambedkar tried to alleviate the apprehensions of the minority communities on Article 44 and asserted, “...the Directive Principles of this Constitution which enjoins the state to seek or to strive to bring about a uniform civil code......I shall also like to point out that the state is claiming in this matter power to legislate. There is no obligation upon the state to do away with the personal laws.It is only giving the power. Therefore, no one needs to be apprehensive of the fact that if the state has the power, the state will immediately proceed to execute or enforce that power in a manner that may be found to be objectionable by the Muslims or Christians or by other community in India. Sovereignty is always limited, no matter even if you assent that is unlimited, because Sovereignty in the exercise of that power must reconcile itself to the sentiments of different communities. No government can exercise its power in such a manner as to provoke the Muslim community to rise in rebellion. I think it would be mad government if it did so. But that is a matter which relates to the exercise of the power and not to the power itself" [6].

So, at the time of independence, a position of contradiction and ambiguity was present in respect of a gender-just common civil code and community cultural rights. On one hand, the Constitution granted freedom of religious and cultural rights as a fundamental right in part III and on the other, it endorsed a provision of uniform civil code as Directive Principle of State Policy in part IV. This duality of provisions comes in the way of reforms in personal laws of different religious communities. As Mahajan describes, "In fact, as is often the case, the norms of equality and diversity, as endorsed in the Constitution of India, push in different directions. If the women's movement has used Article 44 of the Constitution to seek equality for women, minority religious communities have used the commitment to diversity to defend their autonomy. Invoking shared public norms and guaranteed basic rights has not assisted the struggle of women within each community for equal treatment in any way" [7]. More importantly, the identification of uniform civil codes with the homogenisation process reinforces the demand for the continuation of community personal laws. Also, the existence of specific personal laws of various religious communities is regarded as an expression of cultural diversity and generally, defended on this basis.

\section{SHAH BANO CASE CONTROVERSY}

While the Indian constitution granted equal rights to all citizens, irrespective of their religion and region in the public sphere, on the contrary, the state gave priority to cultural rights of the community in the private sphere. This dichotomy between public and public spheres continues to formulate the politics of community identity and gender rights. Moreover, when Muslim women demanded equal rights and justice they didn't get support from the state as well as the community. The Shah Bano controversy clearly manifested this fact. Muslim women's rights have remained a contentious issue of significant discussion and debate in the public sphere since independence, but the Shah Bano controversy in 1984 puts the matter of Muslim Personal Law into centre stage at the national level. It was a watershed event in the way of the struggle for women's right movement. It was based on the right of a divorced Muslim woman to claim maintenance from her ex-husband under the rule of Indian Criminal Procedure Code (hereafter $\mathrm{CrPC}$ ).

The particular case is about a 72 years old Muslim woman Shah Bano, the first wife of a renowned advocate Mohammad Ahmad Khan. In 1978, she filed a case against her ex-husband, claiming for maintenance after divorce as per section 125 of CrPC, in a magisterial court in Indore, Madhya Pradesh. Section 125 of CrPC allows a divorced woman to claim for sufficient maintenance from her ex-husband till she remarried. Her husband defended himself for not giving maintenance in accordance to the Sharia since he is not liable to pay mahrduring the period of iddat(roughly three months) after the divorce. As per Muslim Personal Law, he is not required to pay maintenance to his ex-wife after that period. He further argued that he had already paid maintenance to her as two hundred rupees per month for two years. He also deposited 3,000 rupees in the court as mahr. So, it is not his responsibility to give maintenance after iddatperiod. In August 1979, the local magistrate ordered Khan to pay 25 rupees per month as maintenance to Shah Bano. In 1980, she filed a petition against her husband again for increasing the amount of maintenance on this basis that her husband's income was 60,000 per month. According to Shah Bano's appeal, the High court of Madhya Pradesh increased the amount of maintenance as 179.90 per month. Her husband appealed against the decision of High Court in the Supreme 
Court on the basis of a violation of Muslim Personal Law and also Section 127 of the CrPC. The Supreme Court gave a decision in favour of Shah Bano, asserting that she was entitled to maintenance as per the ruling of Section 125 of CrPC. The court further contended that in the case of a dispute between criminal law and personal code, the former would succeed. Certainly, the Supreme Court ruled in favour of Muslim women empowerment and gave an upper hand to the state's secular laws for providing justice to individuals. It argued for the need of a uniform civil code in place of separate personal laws of communities.

The Supreme Court's judgement created ripples in the whole Muslim society as well as in the political circles. It sparked off an intense debate on the issue of Muslim personal law and the uniform civil code. The decision of the court splits the Muslim community broadly into two factions. Muslim conservative and orthodox leaders vehemently opposed the judgement as it interfered with the Muslim Personal Law and was a frontal attack on their religious rights whereas, the progressive reformative group supported the judgement and they thought it was in concurrence with Muslim Personal Law. However, the fundamentalists mobilised the community mass in opposition of the judgement and demonstrated countrywide. All India Muslim Personal Law Board (AIMPLB) which was established in 1973, argued that a secular court did not have the authority to decide on the matter of religious personal laws of a community. The Board described it an agenda of the majoritarian state to suppress minority community's religious values and hence creating a panic of 'Islam in danger'. A member of AIMPL Board, MaulanaAbul Hasan Ali said, "The Muslim feelings have been deeply hurt by the aggressive attack from all sides on the Muslim Personal Law. The government's wake and doubtful approach and the Supreme Court's judgement have made the future of Islam in this country dishonourable" and similarly, MaulanaAsadMadani warned that "Muslims cannot tolerate any interference in Shari'a which is divine law. If they are compelled in this respect, it can lead to undesirable consequences" [8].

Initially, the Union government led by Sh. Rajiv Gandhi supported the decision. However, G.M. Banatwala, a Member of Parliament, introduced a private member bill to nullify the Supreme Court's judgement. In response to the bill, Ministry of Home Affair note dated 24 July 1985 come to the conclusion that "the provisions of section 125 and 127 are a sort of social legislation meant to prevent vagrancy. It does not seem necessary to amend provisions... to nullify the interpretation given by the Supreme Court in the judgement" [9]. Many eminent Muslim personalities who supported the Supreme Court's judgement gave a joint memorandum to the government for not doing any change in the law to nullify this.

Arif Mohammad Khan a liberal Muslim leader of the Congress Party and a Minister of State in the Ministry of Home Affairs, also vehemently opposed this bill. He supported the Supreme Court judgement for the sake of Muslim women rights and in his speech in LokSabha he said: "I think there is no doubt about the sanctity of the position of woman, her status, and her rights, under the Islamic Law...For divorced women maintenance should be provided on a reasonable scale. This is a duty on the righteous...The women were weak and exploited and used to leading a life of inferiority. It was the crusade of Islam to secure equal rights for all'[10].

However, the intensity of demonstrations and fierce opposition by the Muslim Ulemas compelled Rajiv Gandhi to change his stand. In order to put rest on theagitations, the government decided to reverse the effect of the judgement by introducing a new Bill, Muslim Women (Protection of Rights on Divorce) Bill in the parliament. Many liberal Muslim leaders even within the Congress party were against the bill. Hindu Right accused that the bill was introduced in the Parliament in order to appease Muslim minority by the Congress government. Arif Mohammad Khan, the Union Cabinet Minister, resigned from his post arguing that this bill was "inhuman and anti-Islamic...it will push the Muslim women back to the pre-Islamic era when women were considered as animals, chattel and part of the property" [11]. Benhabib asserts that "Clearly, the purpose of ... this ... the reform bill was to anchor the dependency of women upon a male-dominated, hierarchical structure, either the natal family or the community board. The possibility of assuring the divorced woman's independence through integrating her into a larger civil society and making her to some extent financially autonomous was totally blocked"[12].

There were fierce debates on this issue; progressive Muslim members oppose the bill due to its unconstitutional and undemocratic nature while conservatives welcome the move of the government. The government defended the bill on the ground that it could not ignore the apprehension among Muslim minority in India and it has correctly done this to keep the fabric of unity and cultural diversity intact. K.C. Pant, a Member of Parliament, argued that"There is a need for unity and integration at this time, the need to bring communities together at a time when fundamentalism is growing all around us...We cannot depend only on the law of reforms. The society has to be ready for reform. The well strings of that reform have to come from within and then the law and sentiment that have been aroused by a certain movement, they coincide and then socially moves forwards.Reforms must come from within the Muslim community" [13]. Similarly, Ibrahim Sulaiman, a Member of Parliament from Muslim League said that"In this country which is multi-religious, multilingual and multi-cultural, the idea of achieving national integration through a Common Civil Code is a ... delusion" [14].Amid much hue and cry on the issue, the bill was ultimately passed in the Parliament as Muslim Women 
(Protection of Rights on Divorce) Act 1986. Rajiv Gandhi explained the position of the government and argued that this Act was meant for protection of minority rights. He said, "The Supreme Court passed a judgement in the 'Shah Bano case' which caused... uncertainties in the minds of certain minorities. Whether the uncertainties were founded on something concrete or not is not for us to judge. But the fact is that certain minorities were afraid that certain guarantees given to them at the time of Independence were being diluted"[15].

This was a fundamental deviation in the government's stand from pro-feminist to orthodox paternalist. The Act denied Muslim women their just rights at the time of divorce and placed them at an inferior position in respect to other communities' women. The MWA allows for a one-time payment within the iddat period. Section 3(1) of the Act which tells about: "Mahr or other properties of Muslim women to be given to her at the time of divorce," entails:

"Notwithstanding anything contained in any other law for the time being in force, a divorced woman shall be entitled to-

(a) A reasonable and fair provision and maintenance to be made and paid to her within the iddat period by her former husband;

(b) Where she herself maintains the children born to her before or after her divorce, a reasonable and fair provision and maintenance to be made and paid by her former husband for a period of two years from the respective dates of birth of such children;

(c) An amount equal to the sum of mahr or dower agreed to be paid to her at the time of her marriage or at any time thereafter according to Muslim law; and

(d) All the properties given to her before or at the time of marriage or after her marriage by her relatives or friends or the husband or any relatives of the husband or his friends" [16].

This Act was a big blow on the efforts of the progressive reformist Muslim leaders who not only wanted a gender-equality within the community but also demanded to eliminate discrimination on the basis of religion in the public sphere. Many women's groups agitated and protested against the law as it would further relegate the position of Muslim women in the society. Various eminent scholars also criticised the government move, for instance, Justice Krishna Iyer said:

"The bill is an injustice to our Republic's secular creed; it is an injustice to women's basic rights and, therefore, violative of human rights; it is an assault on the egalitarian policy of our constitution; it is a vindictive challenge to Muslim women by selling the soul of the State's humanism to obscurantist fundamentalists; it is an injustice to the holy Koran which insists on a reasonable provision (mataa) for the maintenance of divorced women; it is an injustice to the $21^{\text {st }}$ century because it throws us back to the $6^{\text {th }}$ century to buy Islamic votes through the noisy illusion of electoral monopolists whose hold on the liberal Muslim intelligentsia..... it is an injustice to family integrity because it is fraught with potential for litigation between close relatives. It is an injustice to the judicial process because, functionally speaking, the provisions appetise these destitute to several cases in search of a pittance; it is an injustice to national stability...The Act also fails to fulfil the present social needs of the Indian community. It is nothing short of a sin being committed as against women in general and to Muslim women in particular. The enactment of such a provision in the name of religion and in the guise of law cannot but bring shame to a country that acclaims social justice" [17]. The Hindu Right misappropriated the Shah Bano controversy and found a political opportunity to demand uniform civil code in the name of women rights for Muslim minority. They projected the uniform civil code "as amagic wand which will ameliorate the woes and sufferings of Indian women in general and Muslim women in particular... It projects the state intervention in the form of an enactment of a uniform code as the only option to bestow gender justice upon minority women"[18]. They alleged that persistent denial of Muslim minority to uniform civil code was a threat to national unity and against the constitutional values. They claimed that the introduction of the Muslim Women Bill was, in fact, an act of 'appeasement of Muslim minority' by the Congress government. In this way, the whole issue of women empowerment and equal rights turns toward communal majority-minority politics at the hands of male-dominated conservative members of both communities. Both exploited the issue of personal law and Muslim women for their own interests. As RatnaKapur and Brenda Cossman asserts: "It was this dichotomized discourse of the debate that inadvertently allied the women's movement with the Hindu Right and its vicious attack on minority rights. Despite the efforts of some feminist activists and organizations to distinguish their position, within the broader political discourse the positions were seen as one and the same. Feminist efforts to challenge the oppression of women within the private sphere of the family were appropriated and transformed to support the communalist discourse of the Hindu Right"[19]. Therefore, the whole issue of gender justice was transformed into a battle of community identity and national unity and in this process, women rights were left behind by the communities as well as the state. Furthermore, the communalisation of the issue in the public domain instilled a sense of fear among common Muslims regarding assimilation and loss of their religious identity by majoritarian fundamental forces. This resulted in backtrack of the community members from taking initiatives for reforms within their personal laws. That is evident in the case of Shah Bano who even after winning a 10 years long battle for gender justice 
in the courts, decided to abandon her claim for maintenance due to the pressure exerted by majoritarian forces to disgrace her community's religious identity. "Thus, even while strongly acknowledging the injustice done to her as a woman, she felt compelled to give up her struggle in order to save her community from attack by Hindu communalists. She was made to feel as if by asserting her rights as a woman, she was exposing her already very vulnerable community to further attack"[20].Therefore, it is imperative on the state to prevent such fundamental forces who tried to exploit the issue of women's justice for their vested communal interests and spread intolerance against the Muslim minority."This hatred campaign can only have the effect of strengthening Muslim fundamentalists and silencing the voice of reform within the Muslim community" [21]. In such a scenario, Muslim community by and large has to play a constructive role to break the orthodox paternalistic shackles that confined the females to merely customary roles in the society.

\section{REFORMS' INITIATIVES IN PERSONAL LAWS: FROM WITHIN THE COMMUNITY OR ABOVE}

It is the responsibility of the state to enforce the women just rights regardless of their incompatibility with religious customs or personal laws. There is no place of such religious personal laws in a democracy those violate the rights of freedom and equality of an individual. No minority community can justify such violations of basic human rights on the basis of group values. The specific reforms in personal laws of a community can be brought in two ways - as reform by the state and reforms comes from within. Ideally the reformative measure should come from within the community owing to the fact that the Muslim minority vehemently opposed any interference or change in community's personal laws by the means of a statute. They seemed it an infringement of their community rights and enforcement of majoritarian values on them. As described by Chandhok, "The Muslim community turned inwards in response to what it perceived as an external threat to its identity. In the process, gender justice was rendered hostage to community identity"[22]. Moreover, the reluctance of the state to initiate such reformative measure due to vote bank politics strengthens conservative voices within the community against any change in the customary religious laws. Various political parties exploit the issue for their own electoral gains and hijack the process of reforms in personal law or towards enacting of the uniform civil code. But if the initiative of reforms comes within the community by liberal reformist and enlightened members, the danger of external threat can be relieved. As Mahajan describes, "Since reforms initiated by the state often meet with hostility and suspicion from the minority community, and principles that are endorsed as universal may reflect the sentiments of the majority within the political community, the idea of accommodating internal minorities democratically through a process of collective deliberation and consensus has won considerable support in recent times...the "reforms from within" approach has gained fairly wide acceptance in minority communities, state machinery and women's groups in India" [23]. However, there come many hurdles for initiating such reforms from within as asserted by Sangari, "the experience of reform of personal law from within...for Muslim has been one of entrenchment of religious elites and a 'community' patriarchy complicit with the state....Apart from the risks of isolation and failure, a struggle to reform personal laws from within puts the onus on a small number of persons" [24].

While exploring the best possible and ideal way to initiate and produce reforms in personal laws of the community in conformity to the wishes of Muslim leaders and intellectuals, such initiatives should come within the community. Although initiatives for reforms may be a challenging and daunting task but it would be the most effective and best-suited approach to bring forth these reforms. Moreover, it would be a non-coercive and relatively more unproblematic way to endorse such changes within their cultural norms. Sometimes, there remains a discord between the community conservative leaders and reformists on the issue of unjust customs and inherently revered community practices. Past experiences have shown that the reforms initiatives originated within the Muslim community have been extremely difficult to materialise. An amicable consensus between various segments of the community is a challenging task. But overall, in a general perception to the community, those reforms from within have much more acceptance than over the above. In order to facilitate reforms in a multicultural polity just like ours, a creative and ingenious societal thrust either from within the minority community or from the above is a pre-requisite. Therefore, for reforms in Muslim Personal Law the state ought to create conducive and necessary conditions. A free unbiased and comprehensive deliberation should be there on each reformative measure. Conservative as well as progressive voices among the community should collaborate with each other for formulating fair and gender-just personal laws. Through this process, the fear of external threat or harm to religious identity can be relieved effectively among Muslims. It would progress towards a more harmonious and cohesive environment among various communities along with ensuring equal individual rights for each gender.

\section{PERSONAL LAWS OR UNIFORM CIVIL CODE: A VEXED MATTER}

The controversy of Shah Bano and Muslim Women Act 1986 highlighted the fact that, instead of resisting the state interference or involvement in the private sphere of the Muslim minority, the orthodox 
Muslim community members, in fact, get the state's support in regulating and restraining women rights. The opposition to granting equal rights to the women was not due to religious beliefs rather it entailed the change in status, proprieties and reduction in paternal dominance. Therefore, in reality, it was a matter of sacrificing of privileges instead of anything else which was carried out by means of collective identity politics coupled with reluctant democratic set up of the country which always remained biased towards women and their rights. Political parties and leadership generally come into the pressure of orthodox patriarchal voices of the communities due to their vested interest and vote bank politics. These institutionalized paternalistic structures always resisted granting equal status greater freedom to women in the guise of traditional and customary practices. The manipulation of these institutional structures along with orthodox religious traditions impaired the process of progressive reforms within personal laws. Consequently, these personal laws, by and large, remains discriminated against women and advantaged male members. In the same perspective, the Supreme Court realised: "Freedom of religion is the core of our culture ... But religious practices, violative of human rights and dignity and sacerdotal suffocation of essentially civil and material freedoms, are not autonomy but oppression. Therefore, a uniform civil code is imperative both for the protection of the oppressed and promotion of national unity and solidarity" [25].

A uniform civil code in a real sense is a matter of providing equal basic rights to women in the society. Its main concern is to render gender-justice and not to disregard collective identities and religious beliefs. In fact, serious deliberations and the inter-community consensus are required to achieve a uniform base for equal basic rights to all individuals irrespective of their religion or culture. In this way, we will able to retain the diversity of all cultural values as well as can overcome discriminatory traditional customary personal laws of all communities. The Shah Bano judgment was a little step in this direction and with the help of substantive efforts of the state in this direction, an amicable solution could have been achieved. But the inherent fallacy present within Indian liberal democracy together with majority-minority framework hindered the genuine attempt for providing gender-just laws for all citizens of the nation. It is true that a democratically chosen government would not stifle the religious feelings of its citizens but this cannot absolve it to perform the constitutional obligation of social justice and equality.

\section{THE CONUNDRUM OF THE PRIVATE AND PUBLIC SPHERE}

Women have always remained as vulnerable members of the society irrespective of the religion or culture. Paternalistic society used them as a tool to negotiate and compensate its enmity with another group. They continued to be the soft targets and the worst victims of the conflicts and contestations among various communities. Their roles are constructed within the domestic and private sphere controlled by the personal laws of the community which remains insulated from the interference from the secular civic laws. Women face multidimensional exploitation at the hands of the community and their gender counterpart. This, in fact, may be considered as a basic cause of their subordination and discrimination. As RatnaKapur and Brenda Cossman say, ".... [The] dominant familial ideology has both shaped and reinforced the public/private distinction, and the construction of the family as private. This understanding of the family as private, and beyond state intervention has operated to both immunize the oppression of women within this domestic sphere, as well as to obscure the extent to which this private sphere is itself created and protected by state regulation" [26].

In specific context of India, there is an excessive control of the paternalistic society in matters of the private sphere and religious customary practices. The male dominated and constructed norms hinder the democratisation of the private domain and strengthen the regressive illiberal uncivilised practices in the society. As Nirmala Banerjee notes, “...in the Indian patriarchal ideology women are regarded more as a highly flexible resource of the household rather than as its full-fledged members. Patriarchal authorities do not necessarily seek to confine women to the limited private space of the household. But they strive to ensure that women's actions in the private or the public domain are tailored to fit in with the designed needs of the former" [27]. Although, the Indian Constitution has provided formal equality and fundamental rights to its all citizens including women in the public sphere but within the private domain, their freedom and equality are curtailed by their own communities. This gendered dichotomy between private and public sphere further oppress the women members as well as violate their basic rights and perpetuate intra-group inequality. This notion of collective rights and community identity in real sense restrain and override individual rights. The communitarian societal perspective is more obligatory and binding on women and restrains their overall capacity as an individual. The created social structure privilege men and therefore, marginalises, subjugates and leads towards the social subordination of women. Implicit within this paradigm is a notion of 'familial ideology' which regulates women's liberty and rights within and outside the private domain.

\section{CONCLUSION}

Muslim community vis-à-vis majority community seeks justice, equality and freedom. They are absolutely justified in their demands. Similarly Muslim women demand gender justice from their own 
community and they are also fully justified. Patriarchal structures are abominable for both majority and minority communities. It is the long demand of women groups that they should be given equal gender rights. However, the Muslim Personal Law does not fully address this issue. In fact, the way Muslim community experiences a kind of alienation and marginalisation in the hands of the majority community, similarly Muslim women within their own community are passing through the same experiences. In the name of protecting personal laws, an internal minorityism is being practised by the Muslim community. Muslim women are its obvious victim. The multicultural conception of collective rights is not justified when the cultural practices of minority communities violate basic human rights of the individuals. If such a case, when these community rights suppress or deny equal rights to their members in this instance the Muslim women, then it is imperative on the state not to allow such illiberal practices and facilitates towards gender-just common laws. No civilized society can justify such illiberal and inhumane practices like female genital mutilation, dowry deaths, female infanticide, the caste systems etc. Such unjust practices ought to be eradicated from the society by joint efforts of the state and the communities.

Hence, gender justice is one of the formidable challenges before the identity politics in general and Muslim society in particular. Certainly, the women's issue can no longer be evaded. The above analysis addresses this issue in its entirety. However, the purpose of this analysis is neither to create a binary between individual and group rights (universal and particular rights) nor to undermine the significance of identity/community politics. The argument is simple and straight, that the basis on which religious identity seeks recognition, equality and freedom from the state and the wider society, on the same basis women demand recognition and equality within the community. Moreover, it is recognised that democratic transition is not a one-day affair; it takes the time to grow, mature and ultimately bear the fruits. However, its goals, direction and the realisation of specified goals are clearly marked from the very outset in any transitory movement. The Muslim Personal Law which signifies the distinct identity of the community is valuable only when it recognises its transitory nature. The issue of gender justice for Muslim women lies in this transitory and evolutionary nature of community personal laws. Both the Muslim community as a whole and women as its vital part must come to terms with an accord that realisation of justice and equality for the community would simultaneously lead to the realisation of gender equality. Empirically, as well as normatively, this is the core component of multiculturalism that cherishes diversities by countering all kinds of exclusion and inequality. The challenges before the politics of Muslim identity should be viewed in this light.

\section{REFERENCES}

[1] Green, Leslie (1995), "Internal Minorities and their Rights" in Will Kymlicka (ed.), The Rights of Minority Culture, Oxford; Oxford University Press, p. 257.

[2] Green, Leslie (1995), "Internal Minorities and their Rights" in Will Kymlicka (ed.), The Rights of Minority Culture, Oxford; Oxford University Press, p. 268.

[3] Hasan, Z., Menon, R. (2005), In a Minority: Essays on Muslims Women in India, New Delhi: Oxford University Press, p. 6.

[4] Shachar, Ayelet (2001), Multicultural Jurisdictions: Cultural Differences and Women's Rights,Cambridge: Cambridge University Press, p. 69.

[5] Austin, Granville (1999), The Indian Constitution: Cornerstone of a Nation, New Delhi: Oxford University Press, p. 54.

[6] Government of India : Constitution Assembly Debates, Vol. VII, pp. 779-780.

[7] Mahajan, Gurpreet (2005), Can intra-group equality cohesion-exist with cultural diversity? Re-examining multicultural frameworks of accommodation in Avigail Eisenberg \& Jeff Spinner-Halev (eds) Minorities within Minorities: Equality, Rights and Diversity, Cambridge: Cambridge University Press, p. 98.

[8] Engineer, Asghar Ali (1987), The Shah Bano Controversy, New Delhi: Orient Longman, p. 209.

[9] Engineer, Asghar Ali (1987), The Shah Bano Controversy, New Delhi: Orient Longman, p. 12.

[10] Government of India :LokSabha Debates, 23 August 1985, pp. 434-445.

[11] Government of India :LokSabha Debates, 5 May 1986, p. 451.

[12] Benhabib, S. (2002), The Claims of Culture: Equality and Diversity in the Global Era, Princeton, New Jersey: Princeton University Press, p. 167.

[13] Government of India :LokSabha Debates, 5 May 1986, p. 390.

[14] Government of India :LokSabha Debates, 5 May 1986, p. 390.

[15] Williams, RinaVerma (2012), "Making Minority Identity: Gender, State and Muslim Personal Law" in Rowena Robinson (ed.) Minority Studies, New Delhi: Oxford University Press, p. 88.

[16] The Muslim Women (Protection of Rights on Divorce) Act, 1986

[17] Krishna lyer, V.R (1987), Justice V.R. Krishna Iyer on the Muslim (Protection of Rights on Divorce) Act 1986, Lucknow: Eastern Book Co., pp.17-18. 
[18] Agnes, Flavia (1999), Law and Gender Inequality: The Politics of Women's Rights in India, New Delhi: Oxford University Press, p.1.

[19] Kapur, Ratna\& Brenda Cossman (1996), Subversive Sites: Feminist Engagements with Law in India, New Delhi: Sage Publications, p. 64.

[20] Kishwar, Madhu (1986), 'Pro Women or Anti-Muslim?: The Shahbano Controversy'Manushi, Issue number 32, 1986, p. 5.

[21] Kishwar, Madhu (1986), 'Pro Women or Anti-Muslim?: The Shahbano Controversy'Manushi, Issue number 32, 1986, pp. 12-13.

[22] Chandhok, N. (1999). Beyond Secularism: The Rights of Religious Minorities. New Delhi: Oxford University Press, p. 9.

[23] Mahajan, Gurpreet (2005), Can intra-group equality cohesion-exist with cultural diversity? Re-examining multicultural frameworks of accommodation in Avigail Eisenberg \& Jeff Spinner-Halev (eds) Minorities within Minorities: Equality, Rights and Diversity, Cambridge: Cambridge University Press, pp. 103-104.

[24] Sangari, K. (1995, Dec.), 'Politics of Diversity: Religious Communities and Multiple patriarchies', Economic and Political Weekly, 30 (51-52), p. 3297.[25] A.I.R. 1995, S.C. p. 1540

[26] Kapur, Ratna\& Brenda Cossman (1996), Subversive Sites: Feminist Engagements with Law in India, New Delhi: Sage Publications, p. 90.

[27] Banerjee, Nirmala (1998),"Household Dynamics and Women in a Changing Economy," in Gender, Population and Development, edited by Maithreyi Krishna Raj, Ratna M. Sudarshan, AbusalehShariff, New Delhi: Oxford University Press, p. 261. 